\title{
POTENSI BAKTERI Pseudomonas sp. DAN Ochrobactrum sp. YANG DI ISOLASI DARI BERBAGAI SAMPEL TANAH DALAM MENDEGRADASI LIMBAH POLIMER PLASTIK BERBAHAN DASAR HIGH DENSITY POLYETHYLENE (HDPE) DAN LOW DENSITY POLYETHYLENE (LDPE)
}

\section{POTENTIAL OF Pseudomonas sp. AND Ochrobactrum sp. ISOLATED FROM VARIOUS SOIL SAMPLE AS DEGRADING BACTERIA OF HIGH DENSITY POLYETHYLENE (HDPE) AND LOW DENSITY POLYETHYLENE (LDPE) PLASTIC}

\author{
*Muhammad Inas Riandi, ${ }_{1}^{1}$ Retno Kawuri, ${ }^{1}$ Sang Ketut Sudirga \\ ${ }^{1}$ Program Studi Biologi F.MIPA Universitas Udayana, Bukit Jimbaran-Bali \\ *)Email: inas riandy25@yahoo.co.id
}

\section{INTISARI}

Plastik tergolong kelompok polimer kompleks multifungsional yang telah menjadi produk konvensional dalam segala sektor kehidupan. Penggunaan plastik dalam skala besar berpengaruh terhadap peningkatan jumlah sampah, seperti jenis plastik High Density Polyethylene (HDPE) dan Low Density Polyethylene (LDPE). Penelitian ini bertujuan untuk memperoleh isolat bakteri Pseudomonas sp. dan Ochrobactrum sp. yang diisolasi dari berbagai sampel tanah di Tempat Pembuangan Akhir (TPA) dan Hutan Mangrove yang terdapat di Bali terhadap tingkat degradasi polimer plastik HDPE dan LDPE. Penelitian ini menggunakan metode pour plate, tahap identifikasi morfologi dan biokimia dengan menggunakan buku Bergey's Manual of Determinative Bacteriology $9^{\text {th }}$ Edition sebagai acuan, tahap screening serta tahap identifikasi spesies dengan menggunakan Vitek 2 Compact System. Evaluasi hasil degradasi dilakukan dengan mengukur perubahan berat kering residu plastik. Hasil isolasi berhasil memperoleh 27 jenis isolat yang tergolong genus Pseudomonas dan Ochrobactrum dengan karakteristik bentuk basil, Gram negatif, katalase positif serta tergolong bakteri non-fermentatif. Isolat 2 yang diisolasi dari TPA Suwung teridentifikasi sebagai spesies Ochrobactrum anthropi dengan kemampuan degradasi HDPE sebesar $20 \%$ dan Isolat 24 yang diisolasi dari TPA Karangasem teridentifikasi sebagai spesies Pseudomonas aeruginosa dengan kemampuan degradasi LDPE sebesar $18,75 \%$.

\section{Kata kunci: Limbah plastik, Biodegradasi, High Density Polyethylene dan Low Density Polyethylene}

\section{ABSTRACT}

Plastics classified as multifunctional complex polymer groups that has become a conventional products in every life sectors. The use of plastics on a large scale has an effect on the increase to the amount of world waste, such as High Density Polyethylene (HDPE) and Low Density Polyethylene (LDPE) plastics. This study, tried to isolate Pseudomonas and Ochrobactrum bacteria from various soil in dumped soil area and mangrove forest in Bali to find out the degradation ability of the bacteria against HDPE and LDPE plastics. The methods used in this study were pour plate method, Biochemical and morphology identification by using Bergey's Manual of Determinative Bacteriology $9^{\text {th }}$ Edition book as a reference, screening test and the determination of bacterial species by using Vitek 2 Compact System. Evaluation of degradation result was done by measuring the weight loss of plastics residues. This study has isolated 27 bacteria that estimated from genus Pseudomonas and Ochrobactrum with characteristics as basil shape, Gram negative, positive catalase and classified as non-fermenter bacteria. Isolate 2 bacteria which isolated from Suwung dumped soil has identified as Ochrobactrum anthropi with the ability of HDPE degradation by $20 \%$ and Isolate 24 which isolated from Karangasem dumped soil has identified as Pseudomonas aeruginosa with the ability of HDPE degradation by $18,75 \%$.

\section{Keywords : Plastics waste, Biodegradation, High Density Polyethylene and Low Density Polyethylene}

\section{PENDAHULUAN}

Bahan plastik semakin banyak digunakan dalam dunia industri baik industri makanan, pakaian, transportasi, konstruksi, medis maupun rekreasi selama kurun waktu 3 dekade terakhir ini (Fadlilah dan Maya, 2014). Material plastik banyak digunakan karena memiliki kelebihan dalam sifatnya yang ringan, transparan, tahan air serta harganya relatif murah dan terjangkau semua kalangan masyarakat. Keunggulan tersebut membuat plastik digemari dan banyak digunakan, sehingga berakibat pada peningkatan jumlah produk plastik yang akan menjadi sampah.

Plastik tergolong salah satu polimer kompleks yang memiliki umur degradasi yang sangat lama. Rentang waktu degradasi yang cukup lama tersebut dikarenakan struktur polimer plastik yang memiliki rantai panjang yang berulang, sehingga memerlukan cukup banyak waktu untuk memotong rantai tersebut menjadi molekul berantai pendek (Asmita et al., 2015).

Setiap tahunnya lebih dari 260 juta ton plastik yang diproduksi di berbagai negara dan tercatat bahwa plastik menyumbangkan sekitar $8-12,7 \%$ dari total limbah padat (Asmita et al., 2015). Selain sebagai penyumbang terbesar limbah padat di lingkungan terrestrial, tercatat pula bahwa dari 260 juta ton plastik yang diproduksi, sekitar 8 juta ton limbah plastik terbawa arus dan menuju laut lepas (Eriksen et al., 2014). Selain sebagai limbah, polimer plastik juga melepaskan berbagai senyawa kimia toksik bila bereaksi dengan komponen biotik maupun abiotik di lingkungan, seperti senyawa Bisphenol A, dioktil ptalat (DOP), vynil khlorida, akri lonitril, meta crylonitril venylidine chloride serta shyrene, dimana tergolong senyawa kimia yang bersifat karsinogenik (Arutchelvi et al., 2008).

Data dari Kementerian Perindustrian yang dikutip dalam Daily Investor (2016) melaporkan bahwa impor produk polietilena (PE) dan polipropilena (PP) terus mengalami peningkatan seiring dengan tumbuhnya konsumsi bahan kimia. Data tersebut menyebutkan, pada tahun 2012 konsumsi PE di Indonesia sekitar 955.000 ton per tahun, yang meningkat menjadi sekitar 1,03 juta ton di tahun 2013, dan diprediksi di tahun 2014 meningkat menjadi 1,11 juta ton. Data lain juga menyikap permasalahan permintaan plastik berbahan dasar Low Density Polyethylene (LDPE) mencapai 9\% dan plastik berbahan dasar High Density Polyethylene (HDPE) mencapai angka $17 \%$ dan akan terus mengalami peningkatan seiring dengan pengembangan industri global (Sagel, 2012).

Berdasarkan hal tersebut, sangat perlu dilakukan pengendalian secara aspek biologis dengan mencari kandidat bakteri pendegradasi polimer plastik sehingga jumlah sampah plastik dapat diminimalisir. Berbagai upaya telah dilakukan oleh pemerintah untuk memecahkan permasalah sampah plastik tersebut, baik secara fisik, kimiawis maupun biologis Dari ketiga metode tersebut telah terbukti bahwa metode 
biologis lebih efektif, efisien dan ramah lingkungan. Metode biologis yang sedang dikembangkan adalah dengan menggunakan mikroorganisme alami yang memiliki kemampuan mendegradasi polimer. Penelitian lebih lanjut oleh Devi et al (2015), menyebutkan bahwa terdapat beberapa bakteri yang mampu mendegradasi polimer plastik salah satunya dari genus Pseudomonas dan Ochrobactrum.

\section{MATERI DAN METODE}

Penelitian ini tergolong jenis penelitian eksplorasi dan eksperimental dengan proses pengambilan sampel dilakukan pada 2 lokasi berbeda, yaitu di daerah Tempat Pembuangan Akhir (TPA) dan hutan mangrove. Tempat Pembuangan Akhir (TPA) yang dijadikan sebagai lokasi pengambilan sampel adalah TPA Suwung Denpasar, TPA Karangasem dan TPA Tabanan, sedangkan hutan mangrove yang dipilih sebagai lokasi pengambilan sampel adalah mangrove Serangan dan mangrove MIC (Mangrove Information Center).

Sampel tanah dari 2 lokasi berbeda, yaitu dari TPA dan hutan mangrove diambil dengan menggunakan metode purposive sampling. Pengambilan sampel pada lokasi TPA dan hutan mangrove dilakukan pada 5 titik yang berbeda dalam satu area yang sama dengan ulangan sebanyak 3 kali, sehingga dalam satu area dapat diperoleh total sampel tanah sebanyak 15 sampel. Sampel tanah yang diambil berupa tanah yang terdapat plastik yang telah terurai secara alami. Sampel tanah diambil pada lapisan atas tanah yang telah digali sedalam $10-15 \mathrm{~cm}$ sebanyak 100 Gram dengan menggunakan sekop dan dimasukkan ke dalam ziplock steril yang telah diberi label. Kemudian sampel tanah disimpan dalam kontainer steril dengan suhu sekitar $4^{\circ} \mathrm{C}$ dan segera dibawa ke laboratorium untuk dianalisis.

\section{Persiapan Polimer Plastik HDPE dan LDPE}

Plastik yang digunakan berupa kantong "kresek" jenis High Density Polyethylene (HDPE) dan Low Density Polyethylene (LDPE) yang diperoleh dari pasar lokal dipotong dengan ukuran $5 \times 1 \mathrm{~cm}$ kemudian disterilisasi dengan menggunakan alkohol $70 \%$ selama kurang lebih 30 menit, lalu dilanjutkan dengan pencucian dengan menggunakan air steril dan dikeringanginkan dengan sinar UV pada Laminar Air Flow selama 30 menit. Untuk mengetahui berat kering awal plastik, potongan tersebut dikeringkan dengan oven pada suhu $80^{\circ} \mathrm{C}$ selama 24 jam, sehingga diperoleh berat murni plastik tanpa kandungan air. Potongan plastik ditimbang menggunakan neraca analytical balance dalam kondisi steril sebagai berat kering awal. Supaya dapat dibedakan, masing-masing potongan plastik diberi tanda.

\section{Isolasi dan identifikasi Bakteri Genus Pseudomonas dan Ochrobactrum}

Proses isolasi awal bakteri menggunakan metode platting method dengan cara sampel tanah dan sampah plastik yang telah diperoleh dari lokasi TPA dan hutan mangrove, diambil sebanyak 10 Gram dan disuspensikan ke dalam botol yang telah diisi dengan $90 \mathrm{~mL}$ larutan salin $0,85 \%$, kemudian suspensi disimpan pada inkubator sheaker dengan suhu $37^{\circ} \mathrm{C}$ selama 30 menit. Setelah proses inkubasi, suspensi kemudian diencerkan dengan metode serial dilution hingga mendapatkan tingkat pengenceran $10^{-6}$. Suspensi yang telah diencerkan kemudian dipipet sebanyak $0,1 \mathrm{~mL}$ pada masing-masing suspensi yang berbeda dan dituang dalam cawan Petri steril, lalu masing-masing dituangkan media King's B Agar yang telah ditambahkan 2\% Polyethylene Glycol (PEG) untuk menguji kemampuan tumbuh isolat dalam lingkungan yang mengandung bahan dasar plastik. Kemudian cawan Petri yang mengandung suspensi diinkubasi secara aerob dalam inkubator dengan suhu $37^{\circ} \mathrm{C}$ selama 48 jam.

Isolat bakteri yang telah berumur 48 jam kemudian dimurnikan dengan menggunakan metode streak for single colonies dan diidentifikasi biokimia untuk mengetahui genus awal dari isolat bakteri. Metode isolasi biokimia meliputi uji katalase, uji produksi gas (oksidase), uji motilitas, uji produksi Indol dan Hidrogen Sulfida $\left(\mathrm{H}_{2} \mathrm{~S}\right)$, uji pewarnaan Gram serta uji fermentasi laktosa. HAsil uji disesuaikan dengan buku acuan Bergey's Manual of Determinative Bacteriology $9^{\text {th }}$ Edition.

\section{Screening Bakteri Pendegradasi Polimer Plastik pada Media Cair}

Media Mineral Salt cair yang telah dibuat sebelumnya, dituangkan sebanyak $25 \mathrm{~mL}$ pada labu Erlenmeyer berukuran $100 \mathrm{~mL}$ dan ditambahkan dengan $0,1 \%$ serbuk HDPE dan LDPE sebagai substrat dan penyuplai karbon. Labu Erlenmeyer kemudian disterilisasi dengan autoclave, lalu sebanyak $1 \mathrm{~mL}$ pada masing-masing medium Mineral Salt cair yang telah ditambahkan oleh glukosa dan suspensi bakteri sebelumnya, digunakan sebagai inokulum untuk setiap labu Erlenmeyer yang berisi serbuk HDPE dan LDPE. Semua labu Erlenmeyer diinkubasi pada inkubator shaker $150 \mathrm{rpm}$ pada suhu $30^{\circ} \mathrm{C}$ selama 4 hari. Pertumbuhan bakteri ditentukan berdasarkan tingkat kekeruhan (Asmita et al., 2015).

\section{Screening Bakteri Pendegradasi Polimer Plastik pada Media Padat}

Pengujian ini diawali dengan media agar yang mengandung HDPE dan LDPE ditambahkan dengan Tween 80 kemudian diinokulasi dengan kultur murni dan disebarkan pada bagian tengah media sepanjang $1 \mathrm{~cm}$. Pengujian zona bening digunakan kontrol negatif berupa media tanpa inokulum.

\section{Uji Degradasi Polimer Plastik dan Uji Persentase Kehilangan Berat Kering}

Metode ini diawali dengan media Mineral Salt cair dengan penambahan glukosa yang telah dibuat sebelumnya, dituangkan sebanyak $25 \mathrm{~mL}$ pada labu Erlenmeyer berukuran $100 \mathrm{~mL}$ dan ditambahkan dengan potongan plastik berukuran $5 \times 1 \mathrm{~cm}$ yang telah diukur berat kering awalnya. Labu Erlenmeyer kemudian disterilkan dalam autoclave, lalu diinokulasi sebanyak $1 \mathrm{~mL}$ suspensi bakteri pada masingmasing labu erlenmeyer. Semua labu Erlenmeyer diinkubasi pada inkubator shaker $150 \mathrm{rpm}$ pada suhu $30^{\circ} \mathrm{C}$ selama 45 hari, lalu dilihat tingkat kekeruhan media dan diukur pula berat kering akhirnya. Potongan plastik yang telah dioven ditimbang berat keringnya. Berikut rumus perhitungan persentase kehilangan berat plastik (Fadlilah dan Maya, 2014) :

$$
\text { kehil angan berat }=\frac{W_{i}-W_{f}}{w_{i}} \times 100 \%
$$

Keterangan:

$\mathrm{Wi}=$ Berat kering awal sebelum degradasi (Gram)

$\mathrm{Wf}=$ Berat kering akhir setelah degradasi (Gram)

\section{Identifikasi spesies bakteri pendegradasi plastik}

Isolat bakteri yang memiliki kemampuan degradasi yang paling baik dilakukan identifikasi hingga tingkat spesies dengan menggunakan metode otomatis yaitu teknologi Vitek 2 
Compact. Vitek 2 Compact adalah alat pemeriksaan mikrobiologik otomatik tertentu untuk identifikasi bakteri dan uji kepekaan antibiotik. Alat tersebut menggunakan colorimetric reagent cards (Gram Negatif, Gram Positif dan ragi/Yeast) yang diinkubasi dan ditafsirkan secara otomatik.

HASIL

Isolasi dan Identifikasi Isolat Bakteri Pseudomonas dan Ochrobactrum
Hasil isolasi sampel tanah dari 5 lokasi berbeda, yaitu dari TPA Suwung Denpasar, TPA Karangasem, TPA Tabanan, mangrove Serangan dan mangrove MIC diperoleh 27 jenis isolat bakteri yang memiliki struktur morfologi dan hasil uji biokimia yang tergolong dalam genus Pseudomonas dan Ochrobactrum. Karakteristik isolat bakteri yang diperoleh selama pengambilan sampel setelah dilakukan uji biokimia ditampilkan pada Tabel 1.

Tabel 1. Hasil Uji Biokimia Isolat Bakteri Pseudomonas dan Ochrobactrum

\begin{tabular}{|c|c|c|c|c|c|c|c|}
\hline Nama Isolat & $\begin{array}{c}\text { Uji } \\
\text { Katalase }\end{array}$ & $\begin{array}{c}\text { Fermentasi } \\
\text { Glukosa }\end{array}$ & $\begin{array}{l}\text { Fermentasi } \\
\text { Laktosa }\end{array}$ & $\begin{array}{c}\text { Uji } \\
\text { Motilitas }\end{array}$ & $\begin{array}{l}\text { Produksi } \\
\text { Indol }\end{array}$ & $\begin{array}{c}\text { Produksi } \\
\text { Hidrogen } \\
\text { Sulfida }\end{array}$ & $\begin{array}{c}\text { Uji } \\
\text { Gram }\end{array}$ \\
\hline $\begin{array}{c}\text { Isolat 1 } \\
\text { (K1T4U1) SWG }\end{array}$ & + & - & - & Motil & - & - & $\begin{array}{c}- \\
\text { (basil) }\end{array}$ \\
\hline Isolat 2 & + & - & - & Motil & - & - & - \\
\hline (K1T2U2) SWG & & & & & & & (basil) \\
\hline $\begin{array}{c}\text { Isolat } 3 \\
\text { (K2T2U1) SWG }\end{array}$ & + & - & - & Motil & - & - & $\begin{array}{c}- \\
\text { (basil) }\end{array}$ \\
\hline $\begin{array}{c}\text { Isolat } 4 \\
\text { (K1T3U3) SWG }\end{array}$ & + & - & - & Motil & - & - & (basil) \\
\hline $\begin{array}{c}\text { Isolat } 5 \\
\text { (K2T2U3) TBN }\end{array}$ & + & - & - & Motil & - & - & $\stackrel{-}{-}$ \\
\hline $\begin{array}{c}\text { Isolat } 6 \\
\text { (K3T1U3) TBN }\end{array}$ & + & - & - & Motil & - & + & $\begin{array}{c}- \\
\text { (basil) }\end{array}$ \\
\hline $\begin{array}{c}\text { Isolat } 7 \\
\text { (K4T3U3) TBN }\end{array}$ & + & - & - & Motil & - & - & $\begin{array}{c}- \\
\text { (basil) }\end{array}$ \\
\hline $\begin{array}{c}\text { Isolat } 8 \\
\text { (K2T2U3) TBN }\end{array}$ & + & - & - & Motil & - & - & $\stackrel{-}{-}$ \\
\hline $\begin{array}{c}\text { Isolat } 9 \\
\text { (K1T2U3) TBN }\end{array}$ & + & - & - & Motil & - & - & $\begin{array}{c}- \\
\text { (basil) }\end{array}$ \\
\hline $\begin{array}{c}\text { Isolat } 10 \\
\text { (K1T4U1) TBN }\end{array}$ & + & - & - & Motil & - & + & $\begin{array}{c}- \\
\text { (basil) }\end{array}$ \\
\hline $\begin{array}{c}\text { Isolat 11 } \\
\text { (K2T4U1) TBN }\end{array}$ & + & - & - & Motil & - & - & $\begin{array}{c}- \\
\text { (basil) }\end{array}$ \\
\hline $\begin{array}{c}\text { Isolat } 12 \\
\left(\mathrm{~K} 1 \mathrm{~T} 2 \mathrm{U}^{+}\right) \mathrm{TBN}\end{array}$ & + & - & - & Motil & - & - & $\begin{array}{c}- \\
\text { (basil) }\end{array}$ \\
\hline $\begin{array}{c}\text { Isolat } 13 \\
\text { (K2T2U1) SRG }\end{array}$ & + & - & - & Motil & - & - & $\begin{array}{l}- \\
\text { (basil) }\end{array}$ \\
\hline $\begin{array}{c}\text { Isolat } 14 \\
\text { (K1T4U2) SRG }\end{array}$ & + & - & - & Motil & - & - & (basil) \\
\hline $\begin{array}{c}\text { Isolat 15 } \\
\text { (K1T3U1) SRG }\end{array}$ & + & - & + & Motil & - & - & $\begin{array}{c}- \\
\text { (basil) }\end{array}$ \\
\hline $\begin{array}{c}\text { Isolat 16 } \\
\text { (K1T1U1) SRG }\end{array}$ & + & - & - & Motil & - & - & $\begin{array}{c}- \\
\text { (basil) }\end{array}$ \\
\hline $\begin{array}{c}\text { Isolat } 17 \\
\text { (K2T1U1) SRG }\end{array}$ & + & - & + & Motil & - & - & $\begin{array}{c}- \\
\text { (basil) }\end{array}$ \\
\hline $\begin{array}{c}\text { Isolat } 18 \\
\text { (K1T3U2) SRG }\end{array}$ & + & - & - & Motil & - & - & $\begin{array}{c}- \\
\text { (basil) }\end{array}$ \\
\hline $\begin{array}{c}\text { Isolat } 19 \\
\text { (K2T4U2) SRG }\end{array}$ & + & - & - & Motil & - & - & $\begin{array}{c}- \\
\text { (basil) }\end{array}$ \\
\hline $\begin{array}{c}\text { Isolat 20 } \\
\text { (K3T3U2) SRG }\end{array}$ & + & - & + & Motil & - & - & $\begin{array}{c}- \\
\text { (basil) }\end{array}$ \\
\hline $\begin{array}{c}\text { Isolat } 21 \\
\text { (K1T5U2) MIC }\end{array}$ & + & - & - & Motil & - & - & $\begin{array}{l}- \\
\text { (basil) }\end{array}$ \\
\hline $\begin{array}{c}\text { Isolat } 22 \\
\text { (K1T3U2) KRG }\end{array}$ & + & - & - & Motil & - & - & $\begin{array}{l}- \\
\text { (basil) }\end{array}$ \\
\hline $\begin{array}{c}\text { Isolat } 23 \\
\text { (K1T2U2) KRG }\end{array}$ & + & - & - & Motil & - & - & $\begin{array}{l}- \\
\text { (basil) }\end{array}$ \\
\hline $\begin{array}{c}\text { Isolat } 24 \\
\text { (K2T3U1) KRG }\end{array}$ & + & - & - & Motil & - & - & $\begin{array}{l}- \\
\text { (basil) }\end{array}$ \\
\hline $\begin{array}{c}\text { Isolat } 25 \\
\left(\mathrm{~K} 1 \mathrm{~T} 3 \mathrm{U}^{+}\right) \mathrm{KRG}\end{array}$ & + & - & - & Motil & - & - & (basil) \\
\hline $\begin{array}{c}\text { Isolat } 26 \\
\text { (K1T3U1) KRG }\end{array}$ & + & - & - & Motil & - & - & $\begin{array}{l}- \\
\text { (basil) }\end{array}$ \\
\hline $\begin{array}{c}\text { Isolat } 27 \\
\text { (K1T4U2) KRG }\end{array}$ & + & - & - & Motil & - & - & $\begin{array}{c}- \\
\text { (basil) }\end{array}$ \\
\hline
\end{tabular}

Berdasarkan Tabel 1. menunjukkan bahwa 27 jenis isolat bakteri yang diisolasi mayoritas memiliki karakteristik berupa uji katalase positif, tidak mampu memfermentasi laktosa dan glukosa, bersifat motil, tidak dapat memproduksi senyawa Indol dan Hidrogen Sulfida serta tergolong bakteri basil Gram negatif. Berdasarkan hasil uji tersebut telah dapat diperkirakan sesuai dengan acuan buku Bergey's Manual of Determinative Bacteriology $9^{\text {th }}$ Edition bahwa isolat bakteri tergolong dari genus Pseudomonas dan Ochrobactrum. 


\section{Hasil Uji Screening Media Cair Bakteri Pseudomonas dan} Ochrobactrum

Hasil uji screening pada media cair diperoleh hasil bahwa ke-27 isolat bakteri menunjukkan tingkat kekeruhan yang tinggi disertai dengan perubahan warna media yang beragam, baik dari media yang mengandung plastik High Density Polyethylene (HDPE) maupun Low Density Polyethylene (LDPE). Perubahan warna yang cenderung ditampilkan berupa perubahan warna media dari bening menjadi bewarna hijau, coklat dan kuning. Perubahan warna media dapat dilihat pada Gambar 1 .
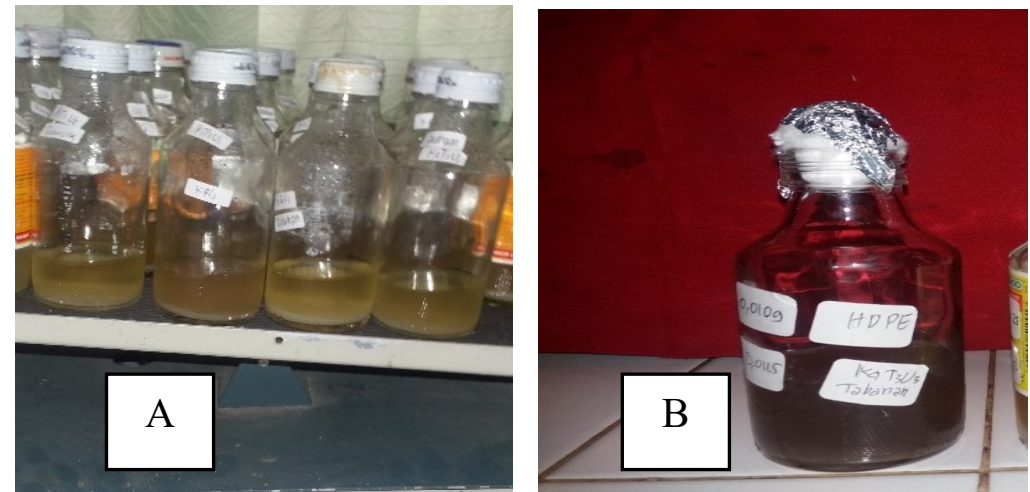

Gambar 1. Perubahan warna media yang ditampilkan oleh isolat bakteri setelah diinkubasi selama 14 hari dan pada suhu $28^{0} \mathrm{C}$ (A: Media yang mengandung plastik Low Density Polyethylene; B: Media yang mengandung plastik High Density Polyethylene)

\section{Hasil Uji Screening Media Padat Bakteri Pseudomonas dan Ochrobactrum}

Hasil uji menunjukkan hanya 5 isolat bakteri yang mampu tumbuh dan membentuk zona bening maupun zona buram di medium yang mengandung plastik HDPE, dimana diameter zona bening terbesar ditampilkan oleh isolat 6 (K3T1U3 TBN), isolat 7 (K4T3U3 TBN) dan isolat 2
(K1T2U2 SWG) yaitu sebesar 0,35 cm. Sedangkan diperoleh 7 isolat bakteri yang mampu tumbuh dan membentuk zona bening maupun zona buram di medium yang mengandung plastik LDPE, dimana diameter zona bening terbesar ditampilkan oleh isolat 24 (K2T3U1 KRG) yaitu sebesar 0,40 $\mathrm{cm}$. Zona bening yang terbentuk dapat dilihat pada Gambar 2.
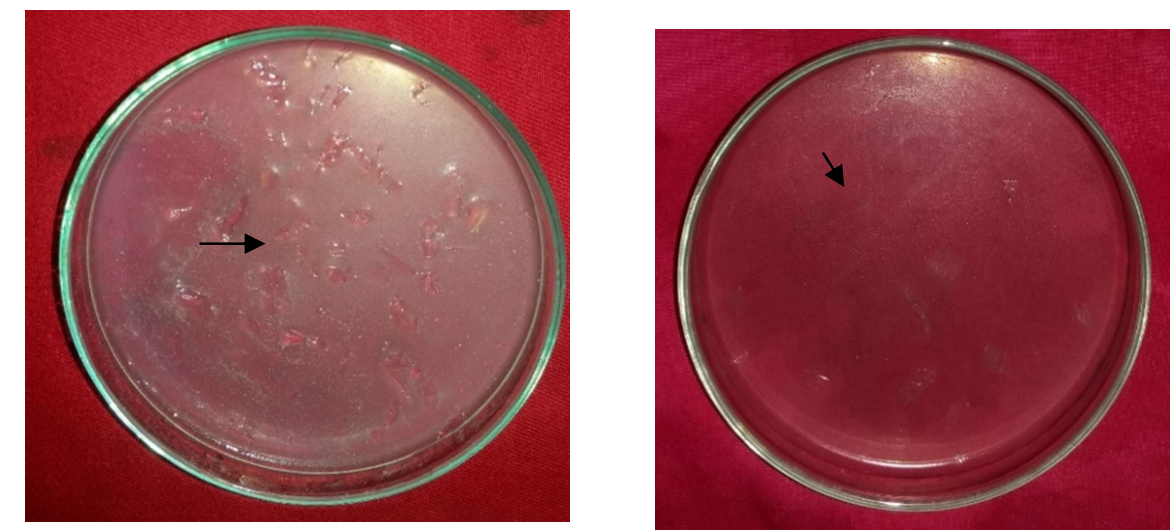

Gambar 2. Zona bening yang dibentuk oleh isolat bakteri yang diinkubasi selama 14 hari dan suhu $28^{\circ} \mathrm{C}$

(A: Media yang mengandung plastik High Density Polyethylene; B: Media yang mengandung plastik Low Density Polyethylene)

\subsubsection{Hasil uji isolat terhadap media yang mengandung polimer plastik}

Hasil uji degradasi polimer plastik diperoleh bahwa isolat 2 (K1T2U2 SWG) memiliki persentase degradasi polimer plastik High Density Polyethylene terbesar yaitu sebesar 20\%, sedangkan isolat 24 (K2T3U1 KRG) memiliki persentase degradasi polimer plastik Low Density Polyethylene terbesar yaitu sebesar $18,75 \%$. Hasil uji degradasi dapat dilihat pada Tabel 2 dan Tabel 3 .

Tabel 2. Hasil uji kemampuan degradasi polimer plastik HDPE

\begin{tabular}{cccccc}
\hline Nama Isolat & $\begin{array}{c}\text { Berat kering } \\
\text { sebelum perlakuan } \\
\text { (Gram) }\end{array}$ & $\begin{array}{c}\text { Berat kering } \\
\text { sesudah perlakuan } \\
(\text { Gram })\end{array}$ & $\begin{array}{c}\text { Selisih berat } \\
\text { (Gram) }\end{array}$ & $\begin{array}{c}\text { Rata-rata } \\
\text { (Gram) }\end{array}$ & $\begin{array}{c}\text { Persentase } \\
\text { kemampuan } \\
\text { degradasi (Gram) }\end{array}$ \\
\hline Isolat 2 & Ulangan 1 $=0,0134$ & Ulangan 1 $=0,0115$ & Ulangan 1 $=0,0019$ & 0,0025 & $20 \%$ \\
K1T2U2 SWG & Ulangan 2 $=0,0118$ & Ulangan 2 $=0,0087$ & Ulangan 2 $=0,0031$ & & \\
& & & & \\
Isolat 7 & Ulangan 1 $=0,0109$ & Ulangan 1 $=0,0090$ & Ulangan 1 $=0,0019$ & 0,0022 & $19 \%$ \\
K4T3U3 TBN & Ulangan 2 $=0,0115$ & Ulangan 2 $=0,0091$ & Ulangan 2 $=0,0024$ & & $16 \%$ \\
Isolat 6 & Ulangan 1 $=0,0125$ & Ulangan 1 $=0,0105$ & Ulangan 1 $=0,0020$ & 0,0020 & \\
K3T1U3 TBN & Ulangan 2 $=0,0132$ & Ulangan 2 $=0,0111$ & Ulangan 2 $=0,0021$ & & \\
\hline
\end{tabular}

Tabel 3. Hasil uji kemampuan degradasi polimer plastik LDPE

\begin{tabular}{cccccc}
\hline Nama Isolat & $\begin{array}{c}\text { Berat kering } \\
\text { sebelum perlakuan } \\
(\text { Gram })\end{array}$ & $\begin{array}{c}\text { Berat kering } \\
\text { sesudah perlakuan } \\
(\text { Gram })\end{array}$ & $\begin{array}{c}\text { Selisih berat } \\
(\text { Gram })\end{array}$ & $\begin{array}{c}\text { Rata-rata } \\
(\text { Gram })\end{array}$ & $\begin{array}{c}\text { Persentase } \\
\text { kemampuan } \\
\text { degradasi (Gram) }\end{array}$ \\
\hline Isolat 6 & Ulangan 1 $=0,0293$ & Ulangan 1 $=0,0229$ & Ulangan 1 $=0,0019$ & 0,0014 & $13,5 \%$ \\
K3T1U3 TBN & Ulangan 2 $=0,0153$ & Ulangan 2 $=0,0145$ & Ulangan 2 $=0,0008$ & & \\
Isolat 24 & Ulangan 1 $=0,0254$ & Ulangan 1 $=0,0179$ & Ulangan 1 $=0,0075$ & 0,0044 & $18,75 \%$ \\
K2T3U1 KRG & Ulangan 2 $=0,0144$ & Ulangan 2 $=0,0132$ & Ulangan 2 $=0,0012$ & & \\
\hline
\end{tabular}




\section{Hasil identifikasi spesies bakteri}

Hasil identifikasi isolat bakteri yang mampu mendegradasi polimer plastik jenis HDPE dan LDPE dengan menggunakan Vitek 2 Compact System menunjukkan hasil bahwa isolat 2 (K1T2U2 SWG) tergolong dari spesies bakteri Ochrobactrum antropi, sedangkan isolat 24 (K2T3U1 KRG) tergolong dari spesies bakteri Pseudomonas aeruginosa.

\section{PEMBAHASAN}

Hasil isolasi sampel tanah diperoleh 27 jenis isolat yang menyerupai genus Pseudomonas dan Ochrobactrum. Identifikasi secara mikroskopis dari isolat yang berhasil diisolasi menunjukkan hasil bahwa keseluruhan isolat Gram negatif dengan uji katalase positif. Bakteri Gram negatif tergolong jenis bakteri yang memiliki membran sel yang tipis dengan ketebalan $8-12 \mathrm{~nm}$, mempunyai 3 lapis membran yaitu membran luar, membran peptidoglycan dan membran plasma, memiliki membran periplasmik serta memiliki kandungan lipid dan lipoprotein yang tinggi (Aryal, 2014). Katalase positif yang ditunjukkan oleh isolat mengindikasikan bahwa isolat memiliki enzim katalase yang mampu mengubah hydrogen peroksida $\left(\mathrm{H}_{2} \mathrm{O}_{2}\right)$ yang berupa produk letal dari hasil sampingan metabolisme aerobik menjadi molekul oksigen dan air.

Hasil penelitian juga berhasil menunjukkan bahwa hampir keseluruhan isolat bersifat motil, yang berarti isolat bakteri memiliki flagella sebagai alat lokomosi dan juga hampir sebagian besar tidak memproduksi senyawa Indol dan hydrogen sulfida $\left(\mathrm{H}_{2} \mathrm{~S}\right)$. Menurut Arora et al (2015), Indol dan Hidrogen Sulfida merupakan salah satu produk dari proses degradasi senyawa L-tryptophan, yang memiliki tingkat toksik yang tinggi bagi manusia maupun mikroorganisme lain.

Tumbuhnya bakteri secara normal pada media yang mengandung polimer plastik dan beberapa unsur nitrogen, dapat mengindikasikan bahwa bakteri mampu mempergunakan unsur karbon dari polimer untuk memenuhi kebutuhan karbon dalam proses metabolismenya (Agustien et al., 2016). Sedangkan perubahan warna media disebabkan oleh pigmen yang dikeluarkan oleh bakteri dan bereaksi terhadap substrat dalam media sehingga membentuk gugus kromofor yang mampu merubah warna media (Charkoudian et al., 2010).

Hasil penelitian ini sesuai dengan penelitian Devi et al. (2015) bahwa spesies Pseudomonas aeruginosa dan Orchobactrum anthropi mampu mendegradasi polimer plastik, dengan ciri utama membentuk zona bening pada media yang mengandung polimer plastik dan berkurangnya berat kering plastik. Proses biodegradasi yang terjadi pada umumnya dipengaruhi oleh interaksi antara enzim yang disekresi oleh mikroorganisme berupa enzim pengkatalis reaksi hidrolisis dan molekul non-enzim yang berasal dari lingkungan ataupun dari mikroorganisme yang dapat merusak struktur polimer (Trevino et al., 2012). Selama proses degradasi, exo-enzim yang disekresikan oleh mikroorganisme akan memecah polimer kompleks menjadi senyawa berantai pendek yang dapat diserap oleh membran bakteri dan dapat dipergunakan bakteri sebagai sumber energi.

Menurut Martinez (2015), pada proses identifikasi spesies secara biokimia salah satu karakteristik utama dari spesies Pseudomonas aeruginosa adalah kemampuannya menghidrolisis senyawa urea menjadi ammonia dan karbondioksida. Menurut Duran et al (2009), bakteri Ochrobactrum anthropi menyerupai bakteri Pseudomonas aeruginosa, karena tergolong water-borne bacteria (bakteri yang berasal dari air) dan mampu menyebabkan infeksi noscocomial, sedangkan yang menjadi faktor pembeda dari kedua spesies bakteri tersebut adalah Ochrobactrum anthropi tidak mampu memproduksi pigmen, baik pigment pyocyanin maupun pigment pyoverdin seperti yang diproduksi oleh spesies Pseudomonas aeruginosa serta memiliki flagella jenis peritrichous.

\section{SIMPULAN}

Penelitian ini diperoleh kesimpulan bahwa isolat 2 (K1T2U2 SWG) yang diisolasi dari Tempat Pembuangan Akhir (TPA) Suwung-Bali teridentifikasi sebagai spesies Ochrobactrum anthropi dengan kemampuan degradasi HDPE sebesar 20\% dan Isolat 24 (K2T3U1 KRG) yang diisolasi dari Tempat Pembuangan Akhir (TPA) Karangasem-Bali teridentifikasi sebagai spesies Pseudomonas aeruginosa dengan kemampuan degradasi LDPE sebesar 18,75\%

\section{UCAPAN TERIMA KASIH}

Ibu Dr. Dra. Retno Kawuri, M.Phil, Dr. Sang Ketut Sudirga, S.Si.,M.Si, Drs.Yan Ramona, M. App. Sc., Ph.D, Drs. Martin Joni, M.Si, dan Bapak I Ketut Muksin, S.Si., M.Si yang telah memberikan bimbingan, saran dan kritik sehingga jurnal ini dapat terselesaikan

\section{KEPUSTAKAAN}

Agustien, A., Mifthahul J. and Akmal D. 2016. Screening Polyethylene Synthetic Plastic Degrading-Bacteria from Soil. Der Pharmacia Lettre, 8 (7): 183 - 187.

Arora, P.K., Ashutosh S. and Hanhong Bae. 2015. Review article: Microbial Degradation of Indole and Its Derivatives. Journal of Chemistry, Vol. 2015. 1 - 13.

Arutchelvi, J., Ambika A., Mukesh D., Sumit B. dan Parasu V.U. 2008. Biodegradation of Polyethylene and Polypropylene. Indian Journal of Biotechnology. 7: 9 22.

Aryal, Sagar. 2014. Differences between Gram Positive and Gram Negative Bacteria. http://www.microbiologyinfo.com/differences-betweengram-positive-and-gram-negative-bacteria/. Dibuka pada tanggal 4 Juni 2017.

Asmita, K., Tanwar S. dan Shanbhag T. 2015. Isolation of Plastic Degrading Micro-organisms from Soil Samples Collected at Various Locations in Mumbai, India. International Research Journal of Environment Sciences. 4(3): $77-85$.

Charkoudian, Louise K. Jay T. Fitzgerald, Chaitan Khosla and Andrea Champlin. 2010, In Living Color: Bacterial Pigments as an Untapped Resource in the Classroom and Beyond. PLOS Biology 8(10): $1-6$.

Daily, Investor. 2016. Banjir Impor, Investasi Kendur http://www.kemenperin.go.id/artikel/6316/Banjir-Impor,Investasi-Kendur. Dibuka tanggal 20,10,2016.

Devi, R.S., Velu R.K., Krishnan N., Duraisamy N., Kanthaiah K., Sekar C. dan Arokiaswamy R.A. 2015. The Role of 
Microbes in Plastic Degradation, dalam Buku Environmental Waste Management (Chandra, R., 2015), pp 341 - 370, CRC Press. India.

Duran, R., Ulfet V., Betul A. and Umit N.B. 2009. Ochrobactrum anthropi bacteremia in a preterm infant with meconium peritonitis. International Journal of Infectious Diseases, 13 (1): 61 - 63.

Eriksen, M., Laurent C.M.L., Henry S.C., Martin T., Charles J.M., Jose C.B., Francois G., Peter G.R. dan Julia R. 2014. Plastic Pollution in the World's Oceans: More than 5 Trillion Plastic Pieces Weighing over 250,000 Tons Afloat at Sea. Plos One. 10: 1-15.

Fadlilah, F. R. dan Maya Shovitri. 2014. Potensi Isolat Bakteri Bacillus dalam Mendegradasi Plastik dengan Metode Kolom Winogradsky. Jurnal Teknik Pomits. 3(2): $40-$ 43.

Martinez, Priscilla. 2015. Soil Sample Pseudomonas aeruginosa.

https://microbewiki.kenyon.edu/index.php/Soil_Sample_ Pseudomonas_aeruginosa. Dibuka pada tanggal 4 Juni 2017.

Sagel, Esteban. 2012. Polyethylene Global Overview. Makalah dipresentasikan pada Forum PeMex Ciudad de Mexico, Juni 2012. Mexico. pp $1-31$.

Trevino, A.L., Gerardo G.S., Raul R.H. dan Cristobal N.A. 2012. Microbial Enzymes Involved in Polyurethane Biodegradation: A Review. J. Polym. Environ. 20: 258 265. 